\title{
GC-MS Analysis and cardiovascular activity of the essential oil of Ocotea duckei
}

\author{
José M. Barbosa-Filho, ${ }^{* 1}$ Renildo M. Cunha, ${ }^{1}$ Celidarque S. Dias, ${ }^{1}$ Petrônio F. Athayde- \\ Filho, ${ }^{1}$ Marcelo S. Silva, ${ }^{1}$ Emídio Vasconcelos L. da-Cunha, ${ }^{1,2}$ Maria Iracema L. Machado, ${ }^{3}$ \\ Afrânio A. Craveiro, ${ }^{3}$ Isac A. Medeiros, ${ }^{*, 1}$
${ }^{1}$ Laboratório de Tecnologia Farmacêutica, Universidade Federal da Paraíba, Caixa Postal, 5009, 58051-970 João Pessoa-PB, Brazil,
${ }^{2}$ Departamento de Farmácia e Biologia, Universidade Estadual da Paraíba, 58100-000 Campina Grande-PB, Brazil,
${ }^{3}$ Parque de Desenvolvimento Tecnológico, Universidade Federal do Ceará, Caixa Postal 6022, 60451-970 Fortaleza-CE, Brazil

\begin{abstract}
RESUMO: "Análise CG-EM e atividade cardiovascular dos óleos essenciais de Ocotea duckei". O óleo essencial obtido da destilação por vapor de água das folhas, caule, raíz e frutos de Ocotea duckei teve sua composição química analisada através de CG-EM. A atividade farmacológica desses óleos também foi avaliada, mostrando significantes efeitos cardiovasculares. Quarenta e nove substâncias foram identificadas, constituída por uma mistura complexa de monoterpenos $(45 \%)$ e sesquiterpenos $(55 \%)$. Os frutos forneceram $(1,9 \%)$ mais óleo essencial do que os caules $(1,0 \%)$, raízes $(0,8 \%)$ e folhas $(0,7 \%)$. O principal componente encontrado nas folhas foi o trans-cariofileno $(60,54 \%)$, nas cascas do caule, $\beta$-eudesmol $(27,51 \%)$ e nos frutos, dl-limoneno (30,12\%). O componente predominante do óleo essencial das raízes foi elemol (24,31\%). Em ratos normotensos, não anestesiados, o óleo essencial de diferentes partes de Ocotea duckei (folhas, frutos, caule e raiz) induziu significante $(p<0,05)$ hipotensão seguido de bradicardia.
\end{abstract}

Unitermos: Ocotea duckei, Lauraceae, óleo essencial, análise CG-EM, atividade cardiovascular.

\begin{abstract}
The essential oils obtained by steam distillation from the roots, stems, leaves and fruits of Ocotea duckei had their composition analyzed by GC-MS. The pharmacological activity of these oils was also evaluated showing significant cardiovascular effects. Forty-nine substances were identified, consisting of a complex mixture of monoterpenes $(45 \%)$ and sesquiterpenes $(55 \%)$. The fruits yielded $(1.9 \%)$ more essential oil than the stems $(1.0 \%)$, roots $(0.8 \%)$ and leaves $(0.7 \%)$. The main component in the oil of the leaves was trans-caryophyllene $(60.54 \%)$, in the stem bark $\beta$-eudesmol (27.51\%) and in the fruits, dl-limonene (30.12\%). The predominant essential oil component in the roots was elemol $(24.31 \%)$. In non-anaesthetized normotensive rats, the essential oils from different parts of Ocotea duckei (leaves, fruits, stem and roots) induced significant $(p<0.05)$ hypotension followed by bradycardia.
\end{abstract}

Keywords: Ocotea duckei, Lauraceae, essential oil, GC-MS analysis, cardiovascular activity.

\section{INTRODUCTION}

The family Lauraceae is constituted by circa 50 genera and approximately 500 species, most of them trees. Its main distribution centers are South America and Southeastern Asia and the plants of this family are known for the production of a wide diversity of secondary metabolites (Brummitt, 1992; Silva et al., 1989; BarbosaFilho et al., 1989a,b; Barbosa-Filho et al., 1987; Lopes et al., 1986). Ocotea duckei is a member of the Lauraceae found in Northeastern Brazil, where it is popularly known as "louro de cheiro". There is no reported use in folk medicine for this plant. A morphoanatomical study of the leaves of Ocotea duckei was carried out in order to contribute to separate it from the other species of the same genus (Coutinho et al., 2006a,b). Previous reports on Ocotea duckei described the isolation of alkaloids (Dias et al., 2003; Silva et al., 2002; Morais et al., 1998a) and lignoids (Morais et al., 1996; Morais et al., 1998b; Morais et al., 1999; Barbosa-Filho et al., 1999). Yangambin, the main lignoid isolated from this species has shown many pharmacological properties, such as: (a) a selective platelet activating factor (PAF) receptor antagonist, observed in several in vitro and in vivo experimental models (Castro-Faria-Neto et al., 1995a,b; Herbert et al., 1997), (b) an effective pharmacological 
agent against cardiovascular collapse and mortality in endotoxin shock (Tibiriçá et al., 1996; Ribeiro et al., 1996; Araújo et al., 2001), (c) an anti-allergic effect (Serra et al., 1997), (d) increased sleeping time induced by pentobarbital and the blockage of convulsions induced by pentylenotetrazole (Almeida et al., 1995; Pachú et al., 1993), (e) yangambin was not mutagenic when tested using strains of Salmonella typhimurium (Marques et al., 2003), (f) topical treatment of eggs and first instars with yangambin as well as feeding larvae with a yangambin-treated diet resulted in inhibition of postembryonic development, morphological alteration, and oviposition reduction (Cabral et al., 2007a,b), (g) yangambin presented antileishmanial activity against promastigotes forms of $L$. chagasi and L. amazonensis (Monte-Neto et al., 2007) and antimicrobial activity against Escherichia coli (Antunes et al., 2006).

This is the first report of the composition of the essential oils obtained from the fruits, leaves, stem and roots of Ocotea duckei, as well as the pharmacological activity on the cardiovascular system.

\section{MATERIAL AND METHODS}

\section{Plant material}

The plant was collected in March 2005, near the city of Santa Rita, State of Paraíba, Brazil. A voucher specimen (Agra 4309) is deposited in the Herbarium Prof. Lauro Pires Xavier (JPB) in the Laboratório de Tecnologia Farmacêutica, Universidade Federal da Paraíba.

\section{Isolation of the essential oils}

The fresh material (1000 g) of each part of the plant was extracted using a steam distillation process in a Clevenger apparatus for $3 \mathrm{~h}$ at a controlled temperature $\left(40{ }^{\circ} \mathrm{C}\right)$ according to the literature (Matos et al., 1999). The yields in terms of percentage of the fresh weight of the different parts of the vegetal were determined.

\section{Analysis of the essential oils}

The essential oils were analyzed by GC-MS, using a Hewlett Packard HP 5890 coupled to a HP 5971A mass selective detector, using the following conditions: Column: SP 2100 dimethylpolysiloxone DB-5 fused silica capillary column $30 \mathrm{~m}$ x $0.25 \mathrm{~mm}(0.1$ $\mu \mathrm{m}$ film thickness). The conditions of the experiment were: carrier gas: He, (1 $\mathrm{mL} / \mathrm{min}$.); programmed column temperature $35-180{ }^{\circ} \mathrm{C}$ at $4{ }^{\circ} \mathrm{C} / \mathrm{min}$. then 180 $-280{ }^{\circ} \mathrm{C}$ at $20{ }^{\circ} \mathrm{C} / \mathrm{min}$. Electron impact MS was used at $70 \mathrm{eV} .1 \mu \mathrm{L}$ of each essential oil was analyzed. The concentration of their components was calculated using the individual peak areas for each substance. Each substance was identified by spectrometric analysis using the Wiley data base, retention times and Kovats indexes (Alencar et al., 1994). Visual analysis of the ther mass spectra and comparison with literature data were used for confirmation of the results.

\section{Animals}

The animals used for all experiments were male Wistar rats $(250-300 \mathrm{~g}$ body weight $)$ housed in conditions of controlled temperature $\left(21 \pm 1{ }^{\circ} \mathrm{C}\right)$ and exposed to a 12 hours light-dark cycle with free access to food (Purina-Brazil) and tap water.

\section{Measurement of arterial blood pressure in non- anaesthetized rats}

Rats were anaesthetized using sodium pentobarbital (60 mg. $\mathrm{kg}^{-1}$, i.p.), and a polyethylene catheter was inserted into the lower abdominal aorta via the left femoral artery. Another catheter was inserted into the inferior vena cava via the left femoral vein for administration of drugs. Both catheters were filled with heparinized saline and led under the skin to exit between the scapulae. Two days later, experiments were performed on non-anaesthetized rats accustomed to their environment, and provided with food and water ad libitum. The arterial catheter was connected to a precalibrated pressure transducer (Statham P23 ID; Gould, Cleveland, OH, USA). The transducer signal was fed to an amplifier-recorder (Model TBM-4M, WPI, Sarasota, FL, USA) and to a personal computer (Pentium $166 \mathrm{MHz}$ ) equipped with an analog-to-digital converter board (CIO-DAS16/JR, Computer Boards, Inc., Mansfield, MA, USA). Using CVMS software (WPI, Sarasota, FL, USA), data were sampled every $500 \mathrm{~Hz}$ and stored on a CD-ROM. Beat-to-beat time series were generated and processed off-line in another Personnal computer. For each cardiac cycle, the computer calculated mean arterial pressure (MAP), and pulse interval (referred to as heart rate). After haemodynamic parameters had stabilized different doses of the essential oil from different parts of Ocotea duckei (OEOD - 1, 5, 10 and 15 mg.kg-1 i.v., randomly) were administered. Successive injections were separated by a time sufficient to allow full recovery of arterial pressure, usually 15 $20 \mathrm{~min}$.

\section{Drugs}

The drugs used were heparin sodium salt (Roche), sodium nitroprusside, sodium pentobarbital (Jansen). OEOD was dissolved in $0.1 \%$ cremophor plus saline for in vivo experiments.

\section{Data analysis}

Values are expressed as mean \pm S.E.M. When 

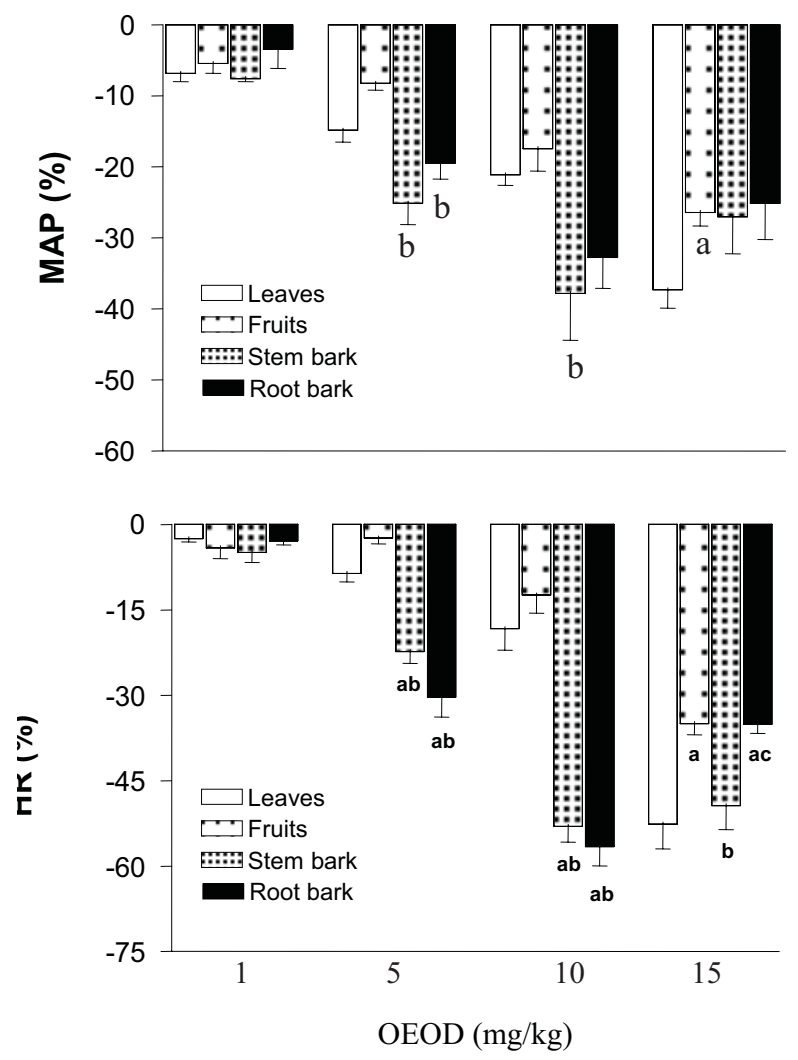

Figure 1. Bar graph showing peak changes in mean arterial pressure (MAP, Top) and in heart rate (HR, Bottom) induced by acute administration of increasing doses $(1,5,10$ and $15 \mathrm{mg} / \mathrm{kg}$, i.v.) of the essential oils from different parts of Ocotea duckei (OEOD) in non-anaesthetized normotensive rats. Results are mean \pm s.e.m $(\mathrm{n}=6) .{ }^{(\mathrm{a})} p<0,05$ vs leaves, ${ }^{(\mathrm{b})} p<0.05$ vs fruits and ${ }^{(\mathrm{c})} p<0.05$ vs stem bark.

appropriate, student's t-test was made to evaluate the significance of the differences between means.

\section{RESULTS AND DISCUSSION}

The essential oils from the different parts of the plant were complex mixtures of mono and sesquiterpenes. Among the 49 identified substances, $45 \%$ were monoterpenes and $55 \%$ were sesquiterpenes.

The fruits of Ocotea duckei yielded the largest amount of essential oil (1.9\% of the fresh weight), when compared with the other parts of the plant, stem bark $(1.0 \%)$, roots $(0.8 \%)$, leaves $(0.7 \%)$. Significant quantitative differences were observed regarding the presence of trans-caryophyllene, which is present as the major component of the leaf oil $(60.54 \%$ of the total oil) and very little in the roots $(0.61 \%$ of the total oil). It is not found in the stem or fruits. dl-limonene, was found in considerable concentration in the fruit oil $(30.12 \%)$, being less present in the stem bark's oil (6.65\%), and not detected in roots or leaves. The main components in the fruit oil are $\beta$-pinene $(12.25 \%)$ and $\alpha$-pinene $(9.89 \%)$. $\beta$-Eudesmol is the main component in the stem bark oil $(27.51 \%)$. This same substance is also found in an important amount in the roots $(13.44 \%)$. The root oil showed elemol $(24.31 \%)$ and $\beta$-elemene $(16.69 \%)$ as its main components. $\alpha$-Pinene, was the only substance found in all parts of the plant: fruits $(9.89 \%)$, stem bark $(9.02 \%)$, roots $(2.89 \%)$ and leaves $(0.62 \%)$. Table 1 , shows the composition of all the oils obtained from the plant parts, as well as molecular weights, retention times and Kovat's index for each component.

In six non-anaesthetized rats, baseline values of mean arterial blood pressure and heart rate were $109 \pm 2$ $\mathrm{mmHg}$ and $360 \pm 9 \mathrm{bpm}$, respectively. The essential oil from the leaves $\left(1,5,10\right.$, and $15 \mathrm{mg} \cdot \mathrm{kg}^{-1}$, i.v., randomly, $\mathrm{n}=6)$ induced significant $(p<0.05)$ hypotension $(7 \pm$ $1,15 \pm 2,21 \pm 2$ and $37 \pm 3 \%$, respectively), followed by intense bradycardia $(3 \pm 1,9 \pm 2,18 \pm 4$ and $53 \pm$ $4 \%$, respectively). OEOD from the fruits $(1,5,10$, and $15 \mathrm{mg} . \mathrm{kg}^{-1}$ i.v., randomly, $\mathrm{n}=6$ ) also induced a marked hypotension $(6 \pm 1,8 \pm 3,18 \pm 3$ and $26 \pm 3 \%$, respectively), which was followed by bradycardia ( $3 \pm$ $2,3 \pm 1,12 \pm 3$ and $35 \pm 2 \%$, respectively). OEOD from stem bark and OEOD from the roots $(1,5,10$, and 15 mg.kg-1 i.v., randomly, $\mathrm{n}=6$ ), were both able to induce hypotension $(8 \pm 1,25 \pm 3,38 \pm 7,27 \pm 5 \%$ and $4 \pm 2$, $20 \pm 2,33 \pm 4,25 \pm 5 \%$, respectively), and bradycardia $(5 \pm 2,22 \pm 2,53 \pm 3,49 \pm 4 \%$ and $3 \pm 1,30 \pm 4,57$ \pm 3 and $35 \pm 2 \%$, respectively). Interestingly, for all of the essential oils tested, the hypotensive effect was more potent on diastolic arterial blood pressure compared with the effect induced on systolic pressure (data not shown).

It is well established that the parasympathetic nervous system plays a significant role in the control of cardiac activity and arterial blood pressure (Higgins et al., 1973). For all of the OEOD tested, hypotension was always followed by bradycardia, indicating a marked participation of cardiac parasympathetic pathways in these responses. It is well reported in the literature that trans-caryophyllene is a calcium channel blocker (Sensch et al., 1993). Thus, we hypothesized that hypotensive and bradycardiac effects might be due to the presence of trans-caryophyllene in the essential oils; however, this may not be the case, since in the essential oils from stem bark and from the fruits hypotension and bradycardia were comparable to that induced by leaves and roots, which do not contain this compound. Furthermore, hypotensive activity for $\alpha$-terpineol was demonstrated in conscious rats (Saito et al., 1996). Nevertheless, this substance was not found in the essential oil from the leaves, which induced hypotension and bradycardia similar to those induced by the other OEOD. Finally, since $\alpha$-pinene was found in all of the essential oils studied, it is a probable candidate for hypotension and bradycardia. As a matter of fact $\alpha$-pinene was reported to induce spasmolytic effect (El Tantawy et al., 1999). However, considering that OEOD from the leaves was able to induce the most important hypotensive and 
Table 1. Composition (\%) of the essencial oils obtained from different parts of Ocotea duckei.

\begin{tabular}{|c|c|c|c|c|c|c|c|}
\hline Compound & MW & $\mathrm{R}_{\mathrm{t}} / \mathrm{min}$. & $\mathrm{KI}$ & $\begin{array}{l}\text { Leaf } \\
(\%)\end{array}$ & $\begin{array}{c}\text { Stem } \\
(\%)\end{array}$ & $\begin{array}{c}\text { Fruit } \\
(\%)\end{array}$ & $\begin{array}{c}\text { Root } \\
(\%)\end{array}$ \\
\hline$\alpha$-Pinene & 136 & 8.22 & 925 & 0.62 & 9.02 & 9.89 & 2.89 \\
\hline Camphene & 136 & 8.65 & 937 & - & 2.41 & 0.88 & 2.22 \\
\hline$\beta$-Pinene & 136 & 9.64 & 965 & - & 2.93 & 12.25 & 1.00 \\
\hline Myrcene & 136 & 10.21 & 981 & - & & 7.86 & - \\
\hline$\delta$-3-Carene & 136 & 10.82 & 998 & - & 0.87 & - & - \\
\hline$\delta$-2-Carene & 136 & 10.88 & 1000 & - & - & - & 1.41 \\
\hline dl-Limonene & 136 & 11.59 & 1020 & - & 6.65 & 30.12 & - \\
\hline 1, 8-Cineole & 154 & 11.67 & 1022 & - & 4.30 & - & 2.53 \\
\hline Linalool & 154 & 14.24 & 1094 & - & - & - & 0.55 \\
\hline Fenchyl alcohol & 154 & 14.66 & 1106 & - & - & 0.64 & - \\
\hline 1-Borneol & 154 & 16.74 & 1164 & - & 6.18 & - & 3.69 \\
\hline Terpinen-4-ol & 154 & 17.08 & 1173 & - & 0.80 & - & - \\
\hline$\alpha$-Terpineol & 154 & 17.57 & 1187 & - & 1.85 & 3.82 & 0.79 \\
\hline$\alpha$-Cubebene & 204 & 23.25 & 1347 & - & 2.20 & - & - \\
\hline$\alpha$-Copaene & 204 & 24.19 & 1373 & 0.74 & 0.80 & - & - \\
\hline$\beta$-Elemene & 204 & 24.98 & 1395 & - & - & - & 16.69 \\
\hline Trans-Caryophyllene & 204 & 26.25 & 1431 & 60.54 & - & - & 0.61 \\
\hline$\alpha$-Humulene & 204 & 27.03 & 1453 & 4.63 & - & - & 0.57 \\
\hline$\beta$-Selinene & 204 & 27.46 & 1464 & - & - & - & 0.58 \\
\hline$\alpha$-Guaiene & 204 & 27.84 & 1475 & - & - & - & 1.21 \\
\hline$\delta$-Selinene & 204 & 28.20 & 1485 & 4.40 & - & - & - \\
\hline$\alpha$-Muurolene & 204 & 28.37 & 1490 & 0.83 & - & - & - \\
\hline$\beta$-Bisabolene & 204 & 28.60 & 1496 & 1.32 & - & - & - \\
\hline$\delta$-Cadinene & 204 & 29.07 & 1510 & 1.69 & 2.38 & - & 0.83 \\
\hline Nerolidol & 222 & 30.11 & 1539 & - & & 1.46 & - \\
\hline Elemol & 222 & 30.15 & 1540 & - & 1.03 & - & 24.31 \\
\hline Guaiol & 222 & 31.27 & 1571 & - & 3.22 & - & 2.10 \\
\hline Epiglobulol & 222 & 32.91 & 1617 & - & & 8.16 & - \\
\hline$\beta$-Eudesmol & 222 & 33.10 & 1623 & - & 27.51 & - & 13.44 \\
\hline Unidentified & & & & 25.23 & 27.85 & 24.92 & 24.58 \\
\hline
\end{tabular}

$\mathrm{MW}=$ Molecular weight; $\mathrm{T}_{\mathrm{R}}=$ Retention time; $\mathrm{KI}=$ Kovats index.

bradycardic effects, and since the lowest amount of the compound was found in the OEOD from the leaves, this might not be the only compound responsible for the cardiovascular effects observed. Whatever the underlying additional mechanisms, the results shown herein suggest that the hypotensive and bradycardiac action of OEOD from different parts of the plant might be due to the presence of one and/or to the association of different compounds present in the essential oil of Ocotea duckei. Furthermore, for all of the OEOD tested we suggest that the hypotensive response is probably due to a decrease in total peripheral resistances associated with a cardiac parasympathetic stimulation (direct and/ or indirect), which might in turn reduce cardiac output and consequently decrease mean arterial pressure.

\section{ACKNOWLEDGMENTS}

The authors are grateful to CNPq, CAPES and IMSEAR for grants and fellowships.

\section{REFERENCES}

Alencar JW, Craveiro AA, Matos FJA 1994. Kovats indices as a preselection routine in mass spectra library searches of volatiles. J Nat Prod 47: 890-892.

Almeida RN, Pachú CO, Barbosa-Filho JM 1995. Avaliação da possível atividade analgésica da iangambina obtida da Ocotea duckei Vattimo. Ciência Cultura Saúde 14: 7-10.

Antunes RMP, Lima EO, Pereira MSV, Câmara CA, Arruda TA, Catão RMR, Barbosa TP, Nunes XP, Dias CS, Silva TMS 2006. Atividade antimicrobiana "in vitro" e determinação da concentração inibitória mínina (CIM) de fitoconstituintes e produtos sintéticos sobre bactérias e fungos leveduriformes. Rev Bras Farmacogn 16: 517-524.

Araújo CV, Barbosa-Filho JM, Cordeiro RSB, Tibiriçá EV 2001. Protective effects of yangambin on cardiovascular hyporeactivity to catecholamines in rats with endotoxin-induced shock. Naunyn Schimiedeberg's Arch Pharmacol 363: 267-275.

Barbosa-Filho JM, Yoshida M, Gottlieb OR, Barbosa RCSBC, Giesbrecht AM, Young MCM 1987. Benzoyl esters and amides, styrylpyrones and neolignans from the fruits of Aniba riparia. Phytochemistry 26: 2615-2617.

Barbosa-Filho JM, Yoshida M, Gottlieb OR 1989. Lignoids from Nectandra amazonum and Nectandra glabrescens. Phytochemistry 28: 1991-1991. 
Barbosa-Filho JM, Silva M.F.GF, Yoshida M, Gottlieb OR 1989. Neolignans from Licaria aurea. Phytochemistry 28: 2209-2211.

Barbosa-Filho JM, Vargas MRW, Silva IG, França IS, Morais LCSL, Cunha EVL, Silva MS, Souza MFV, Chaves MCO, Almeida RN, Agra MF 1999. Ocotea duckei: Exceptional source of yangambin and other furofuran lignans An Acad Bras Cien 71: 231-238.

Brummitt RK 1992. Vascular Plant Families and Genera. Royal Botanic Gardens, Kew; 594-595.

Cabral MMO, Mendonca PM, Gomes CMS, BarbosaFilho JM, Dias CS, Soares MS, Queiroz MMC 2007a. Biological activity of yangambin on the postembryonic development of Chrysomya megacephala (Diptera: Calliphoridae). $J$ Med Entomol 44: 249-255.

Cabral MMO, Mendonca PM, Gomes CMS, Barbosa-Filho JM, Queiroz MMC, Melo RP 2007b. Biological activity of neolignans on the post-embrionic development of Chrysomya megacephala. Fitoterapia 78: 20-24.

Castro-Faria-Neto HC, Bozza PT, Barbosa-Filho JM, Tibiriçá EV, Cordeiro RSB 1995a. Yangambin: a new naturally occurring platelet activating factor receptor antagonist: binding and in vitro functional studies. Planta Med 61:101-105.

Castro-Faria-Neto HC, Araújo CV, Bozza PT, Thomas G, Barbosa-Filho JM, Cordeiro RSB, Tibiriçá EV 1995b. Yangambin: a new naturally occurring platelet activating factor receptor antagonist: in vivo pharmacological studies. Planta Med 61:106-112.

Coutinho DF, Agra MF, Basílio IJLD, Barbosa-Filho JM 2006a. Morphoanatomical study of the leaves of Ocotea duckei Vattimo (Lauraceae-Lauroideae). Rev Bras Farmacogn 16: 537-544.

Coutinho DF, Agra MF, Barbosa-Filho JM, Basílio IJLD 2006b. Morfo-anatomia foliar de Ocotea gardneri (Meisn.) Mez (Lauraceae-Lauroidae). Rev Bras Farmacogn 16: 178-184.

Dias CS, Silva IG, Cunha EVL, Silva MS, Braz-Filho R, Barbosa-Filho JM 2003. Isolamento e identificação de novos alcalóides de Ocotea duckei Vattimo (Lauraceae). Rev Bras Farmacogn 13(Supl.): 62-63.

El Tantawy, ME, El Sakhawy FS, El Sohly MA, Ross SA 1999. Chemical composition and biological activity of the essential oil of the fruit of Taxodium distichum (L.) Rich growing in Egypt. J Essent Oil Res 11: 386-392.

Herbert JM, Castro-Faria-Neto HC, Barbosa-Filho JM, Cordeiro RSB, Tibiriçá EV 1997. Pharmacological evidence for the putative existence of two different subtypes of PAF receptors on platelets and leukocytes; studies with yangambin. J Lipid Mediators Cell Signalling 17: 1-14.

Higgins CB, Vatner SF, Braunwald E 1973. Parasympathetic control of the heart. Pharmacol 25: 119-124.

Lopes MN, Silva MS, Barbosa-Filho JM, Ferreira ZS, Yoshida M, Gottlieb OR 1986. Unsual benzofuranoid neolignans from Licaria chrysophylla. Phytochemistry 25: 2609-2612.

Marques RCP, Batistuzzo-de-Medeiros SR, Agnez-Lima LF, Dias CS, Barbosa-Filho JM 2003. Evaluation of the mutagenic potential of yangambin and of the hydroalcoholic extract of Ocotea duckei by the Ames test. Mutat Res 536: 117-120.

Matos FJA, Machado MIL, Craveiro AA, Barbosa-Filho JM, Cunha EVL, Hiruma CA 1999. Essential oil of Mentha $x$ villosa from Northeastern Brazil. J Essent Oil Res 11: 41-44.

Monte-Neto RL, Barbosa-Filho JM, Sousa LMA, AthaydeFilho PF, Dias CS, Oliveira MR 2007. Crude ethanolic extract, lignoid fraction and yangambin from Ocotea duckei (Lauraceae) show antileishmanial activity. $Z$ Naturforsch 62c: 348-352.

Morais LCSL, Pachú CO, Santos VL, Barbosa-Filho JM 1996. New lignan from Ocotea duckei. Fitoterapia 67: 557.

Morais LCSL, Barbosa-Filho JM, Almeida RN 1998a. Central depressant effects of reticuline extracted from Ocotea duckei in rats and mice. J Ethnopharmacol 62: 57-61.

Morais LCSL, Pachú CO, Santos VL, Athayde-Filho PF, Almeida RN, Barbosa-Filho JM 1998b. (+)-4'-O-demethylepimagnolin A from Ocotea duckei. Fitoterapia 69: 91-92.

Morais LCSL, Almeida RN, Cunha EVL, Silva MS, BarbosaFilho JM, Gray AI 1999. Further lignans from Ocotea duckei. Pharma Biol 37: 144-147.

Pachú CO, Almeida RN, Barbosa-Filho JM 1993. Atividade depressora do sistema nervoso central pela iangambina. Ciência Cultura Saúde 12:14-16.

Ribeiro R, Carvalho FAS, Barbosa-Filho JM, Cordeiro RSB, Tibiriçá EV 1996. Protective effects of yangambin a naturally occurring platelet activating factor (PAF) receptor antagonist on anaphylatics shock in rats. Phytomedicine 3: 249-256.

Saito K, Okabe T, Inamori Y, Tsujibo H, Miyake Y, Hiraoka K, Ishida N 1996. The biological properties of monoterpenes and hypotensive effects on rats and antifungal activites on plant pathogenic fungi of monoterpenes. Mokuzai Gakkaishi 42: 677-680.

Sensch O, Vierling W, Brandt W, Reiter M 1993 Calciumchannel blocking effect of constituents of clove oil. Planta Med (Suppl. 59): A687-A690.

Serra MF, Diaz BL, Barreto EO, Pereira APB, Lima MCR, Barbosa-Filho JM, Cordeiro RSB, Martins MA, Silva PMR 1997. Anti-allergic properties of the natural PAF antagonist yangambin. Planta Med 63: 207-212.

Silva MFGF, Barbosa-Filho JM, Yoshida M, Gottlieb OR 1989. Benzodioxane and beta-aryloxyaryllpropane neolignans from Licaria chrysophylla. Phytochemistry 28: 3477-3482.

Silva IG, Lacerda CDG, Barbosa-Filho JM, Silva MS, Cunha EVL 2002. Coclaurine from Ocotea duckei. Biochem Syst Ecol 30: 881-883.

Tibiriçá EV, Mosquera K, Abreu M, Ribeiro R, Carvalho FAS, Barbosa-Filho JM, Cordeiro RSB 1996. Antagonistic effect of yangambin on platelet activating factor (PAF)-induced cardiovascular collapse. Phytomedicine 2: 235-242. 